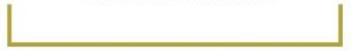

\title{
Workers Who Benefit from the Exploitation of Other Workers
}

\author{
MARCEL VAN DER LINDEN \\ International Institute of Social History, The Netherlands \\ $\underline{\text { mvl@iisg.nl }}$
}

\begin{abstract}
Often, all too often, global working-class solidarity remains fragile, conditional or fails to be realized in practice, whatever the lofty rhetoric may be. The present paper explores one possible explanation: workers in the North profit from the exploitation of workers in the South through cheap commodities and services, and additional job opportunities. For example, wage-earners in the North can buy Tshirts so advantageously because their real wages are much higher than the real wages of labourers in the Global South. This is what I would like to call a relational inequality within the world working class: some workers are better off because other workers are worse off. The paper presents a very tentative historical outline of global relational inequality since the 1830 s.
\end{abstract}

Keywords: solidarity, inequality, consumption, employment, international division of labour, imperial mode of living 
"Subtly they had been bribed, but effectively: Were they not lordly whites and should they not share in the spoils of rape? High wages in the United States and England might be the skillfully manipulated result of slavery in

Africa and of peonage in Asia."

W.E.B. Dubois $(1920)^{1}$

\section{The challenge}

Real international solidarity, a solidarity which has visible positive effect, has often proved difficult to achieve. There have been some magnificent examples of workers' solidarity across borders during the last two centuries - for example, when the First International organized cross-national support for strikers in the 1860 s, or when dockers protested against apartheid by boycotting South African cargo worldwide in the 1980s. But often, all too often, international solidarity remains fragile, conditional or fails to be realized in practice, whatever the lofty rhetoric may be. The collapse of the Second International in 1914 is the most spectacular and tragic failure, of course. But the twentieth century has witnessed many other tragedies, including the refusal of many metropolitan trade-union movements and labour parties to give real support to the anti-colonial struggles in Africa and Asia after World War II.

Why is working-class internationalism so difficult to achieve? Why could workers so often be seduced by jingoism and xenophobia? Why do Northern workers frequently behave indifferently towards the misery of workers in the Global South? Socialists have been discussing these questions for a long time, across the world. Often these discussions are framed in moral or even moralistic terms (e.g., Christian notions of universal charity). A materialist approach however demands that we address at least the following issues: i) the dynamics of global capitalism and its ramifications for the emancipation of the world working class; ii) the relationship between this capitalist dynamic and changing moralities; iii) the fear of slightly 'privileged' workers for deteriorating living conditions; and iv) the necessary conditions for organizing countervailing power and a radical counter-culture. The issue is as important as it is complex; its analysis can only proceed step by step.

1 “The Souls of White Folk", in W.E.B. DuBois, Writings (New York: The Library of America, 1986 [1920]), 923-938, at 935. 


\section{First step}

The present paper wants to reflect on just one specific thesis, which concerns the differences in wealth of segments of the world working class. Wage-earners in the Global North can buy T-shirts cheaply because their real wages are much higher than the real wages of labourers in the Global South. What is more, this may apply as well to indispensable achievements in the living standard of the Northern working class, such as all household appliances and electronic communication and media devices. In that sense workers in the North benefit from and rely on the exploitation of workers in the South. This is what I would like to call a relational inequality within the world working class: some workers are much better off than they were in the past, because other workers, who may also be better off than they were in the past, are vastly lagging behind in living standard and thence, are in absolute terms worse off than their Northern class brothers and sisters.

The idea of such a relational inequality is already old, and it was consistently articulated by socialists. Lenin put forward such an idea already in 1907, in the context of discussions about colonial policy, although it seems he did not regard it necessarily as a durable, structural feature at that time:

Marx frequently quoted a very significant saying of Sismondi's. The proletarians of the ancient world, this saying runs, lived at the expense of society; modern society lives at the expense of the proletarians.... Only the proletarian class, which maintains the whole of society, can bring about the social revolution. However, as a result of the extensive colonial policy, the European proletarian partly finds himself in a position where it is not his labour, but the labour of the practically enslaved natives in the colonies, that maintains the whole of society. The British bourgeoisie, for example, derives more profit from the many millions of the population of India and other colonies than from the British workers. In certain countries this provides the material and economic basis for infecting the proletariat with colonial chauvinism. Of course, this may be only a temporary phenomenon, but the evil must nonetheless be clearly realised and its causes understood in order to be able to rally the proletariat of all countries for the struggle against such opportunism. This struggle is bound to be victorious, since the 'privileged' nations are a diminishing fraction of the capitalist nations. ${ }^{2}$

At the end of World War I, Nikolai Bukharin made this idea more explicit in his book Imperialism and World Economy (1918), in which he wrote: "The

2 Lenin, "The International Socialist Congress in Stuttgart", in Lenin Collected Works, vol. 13 (1972): 77. 
colonial policy yields a colossal income to the great powers, i.e., to their ruling classes, to the 'state capitalist trust.' This is why the bourgeoisie pursues a colonial policy. This being the case, there is a possibility for raising the workers' wages at the expense of the exploited colonial savages and conquered peoples."3

Similar ideas continued to be suggested in later decades as well. Su Lin Lewis reports about the Asian Socialist Conference, held in Rangoon in 1953:

a story recounted by Indonesian socialist Hamid Algadri in his memoirs about one of the British Labour Delegation waking him up in his hotel room late at night to find out why the Asian Socialists were refusing to unite with the Socialist International. Algadri, confused, had told him he was not the right person to ask, but that he was inclined to agree with the resolution, based on the great differences in wages, rights, and living standards between the British and Indonesian laborer. When the European socialist outlined plans for providing aid to 'underdeveloped areas', Algadri asked why, realistically, would British workers want to give up part of their hardearned rights and income to help socialists in Asia, and that in comparison to the Asian laborer, the European laborer was a 'capitalist' from the viewpoint of income and salary. After a moment of silence, the European acknowledged that he was beginning to understand the Asian Socialist position and left. ${ }^{4}$

The first attempt to systematically theorize relational inequality was a hefty volume on Imperialismus published by the Luxemburgist economist Fritz Sternberg in 1926, arguing that the prosperity of the metropolitan working classes was financed through colonial exploitation. ${ }^{5}$ Sternberg's work was never translated into English, and therefore made little impact in Englishspeaking circles. But in exile, in New York in the 1940s, Sternberg repeated his argument in a book on The Coming Crisis (1947). This led to an interesting critique of the influential mainstream economist Abba Lerner. "An ordinary economist", Lerner wrote in the journal Social Research "might think that the growth of real wages of workers in capitalist countries could be connected with the growth of productivity as capitalism developed. ... It would be possible to raise the living standard of the workers by the simple device of

3 Nikolai Bukharin, Imperialism and World Economy. Introduction by Lenin (London: The Merlin Press, 1972) [Mirovoe khoziaistvo $i$ imperializm.

Ekonomicheskii ocherk, Priboi, Peterburg, 1918], 164.

4. Su Lin Lewis, "Asian Socialism and the Forgotten Architects of Post-Colonial Freedom, 1952-1956”, Journal of World History, 30, 1-2 (June 2019): 55-88, at 70. A similar point is made in Ram Manohar Lohia, The Third Camp in World Affairs (Bombay: Praja Socialist Party, 1950), 6-7.

5 Fritz Sternberg, Der Imperialismus (Berlin: Malik-Verlag, 1926). 
producing more, so that they (and the capitalists too, of course) have had more. It would not be so essential to find nonexistent markets abroad.”6

I suspect that there is truth in the arguments of both antagonists (colonial exploitation versus endogenous increase of productivity). Differential labour productivities have certainly contributed significantly to the divergence between North and South. But it can also not be denied that at least some of this global inequality is relational. The approach represented by Abba Lerner has had many followers, and much research has been done on diverging productivities. The approach represented by Fritz Sternberg, however, has been much neglected by scholars - although it has popped up time and again, e.g. in the writings of Arghiri Emmanuel, and more recently Zak Cope. ${ }^{7}$

\section{A first attempt to meet the challenge}

Workers can benefit -I deliberately avoid here the concept "exploitation"from the exploitation of other workers either directly or indirectly. And this may entice them to consciously or unconsciously give priority to their sectional interests over general class interests. Direct benefiting can take two forms: either individual working-class families employ other workers at a wage-level far below their own wage-level (as was the case with the white South African workers employing black houseboys around 1900) or Northern working-class organizations employing Southern workers, as in the case of British consumer cooperatives which owned plantations for cash crops in West-Africa and Ceylon. All such direct benefits seem to have remained rather marginal. Indirect benefits seem to have been much more important. I see a number of possible varieties of indirect benefiting, but there may be more.

a) Import of cheap commodities from the South. This could include the import of consumer goods in the North from the South (consumed by workers in the North) that are produced for wages in the South that are lower than the wages workers would have earned in the North if they had produced the same or equivalent goods. (Child labour plays a role here as well, of course.)

6 Abba Lerner, review of Fritz Sternberg, The Coming Crisis (New York: John Day, 1947), in Social Research, 15, 1 (March 1948): 125-129.

7 Arghiri Emmanuel, Unequal Exchange. A Study of the Imperialism of Trade. Trans. Brian Pearce (New York and London: Monthly Review Press, 1972); Zak Cope, Divided World Divided Class: Global Political Economy and the Stratification of Labour under Capitalism (Montreal: Kersplebedeb, 2012); Zak Cope, The Wealth of (Some) Nations (London: Pluto Press, 2019). 
b) Buying of cheap services in the South. This could include Northern workers enjoying services (e.g. tourism and prostitution) in the South where workers earn less than workers in the North would earn if they were to provide the same services. The same goes for outsourced call centres, etc.

c) Export of commodities (consumer goods, machines, etc.) from the North to the South -because the South cannot produce these commodities or cannot produce these commodities cheap enough- which creates additional job opportunities in the North. E.g., complicated integrated structures such as airplanes, or, as in shipbuilding, rough manufacturing such as ship hulls which are produced in the south, whilst the final production is in the north

d) Transport. The import and export of cheap commodities, tourism in lowwage locations, and so on, may lead to additional job opportunities in logistics for workers from the North (railway personnel, sailors, dockers, truck drivers, etc.).

e) Financial services. All these economic activities $(a, b, c, d)$ may lead to banking and insurance activities, and therefore, to increased employment for Northern workers in the financial sector.

In short: workers in the North may probably mainly benefit from the exploitation of workers in the South in two ways: workers (1) enjoy more purchasing power (cheap commodities and services) and/or (2) have more or better jobs because capitalist enterprises operate in special ways in the Global South. Indirect profiting seems to be the real issue here.

(There is, of course, an additional factor contributing to relational inequality: the income of Northern states that is based on colonial/imperialist exploitation and which is partly used for social provisions, such as good education, healthcare, etc. I leave this element here aside.)

I will focus on two main periods: the first international division of labour, 1830s-1940s, and the era of Fordism and post-Fordism, from the 1940s to the present. This in order to establish a firm foundation for further work on this issue; which will deal with possible future developments.

\section{The first international division of labour, 1830s-1940s}

From around 1750 to 1950 , capitalist industrialization was largely limited to the North Atlantic region. Large parts of the Global South tendentially deindustrialized. Patrick O'Brien has estimated that "the share of world industrial output emanating from production located within third-world 
economies declined from around 70 percent, 1750-1800, down into the 10 percent range, ca. 1950." 8 In the South, agriculture shifted increasingly from subsistence to commodity-production; it supplied especially tropical and subtropical cash crops and South American meat, while the North now provided manufactured goods.

This first international division of labour occurred in a global market that may be characterized as semi-capitalist. As Ken Tarbuck noted: "Many of the recipients of the capitalist commodities produced in Britain (and increasingly in Western Europe and America) did not have capitalist economies. More particularly, the commodities which were imported into the capitalist countries were, by and large, still produced in a non-capitalist manner."9

From the 1870s, this development culminated in the first stage of globalization. Harry Magdoff has noted that during the final decades of the nineteenth century a new global pattern of economic relations emerged, with three distinctive traits: "(1) the number of commodities entering international trade on a large scale multiplied greatly, (2) competition between many widely separated regions of the world first appeared or grew more intense, and (3) the standard of living of workers and the profitability of industry in European nations came to depend on maintenance of overseas supplies, while the standard of living of the producers of raw materials came to depend on market fluctuations occurring sometimes on the other side of the world." ${ }^{10}$ During the interwar years global growth slowed, world trade declined, and autarkic tendencies arose in the Global South.

The problems of the capitalist world economy seemed to worsen, as a result of the establishment of the Soviet Union after 1917 and the extension of "real existing socialism" to Eastern Europe, China, etc. following the Second World War. These developments had two main consequences: capitalist enterprise ceased to be possible in a considerable part of the world, and for several decades a concrete alternative to capitalism seemed to have come about: the centrally planned economy. ${ }^{11}$

8 Patrick Karl O'Brien, "Industrialization", in The Oxford Handbook of World History, ed. Jerry H. Bentley (Oxford: Oxford University Press, 2011), 304-324, at 309. O'Brien means "manufacturing", when he writes "industry."

9 Kenneth Tarbuck, "Marxism in the New Age: Towards the Twenty-First Century", New Interventions, 3, 3 (1992) [Part 3.1].

10 Harry Magdoff, The Age of Imperialism. The Economics of U.S. Foreign Policy (New York: Monthly Review Press, 1969), 32.

11 The competition between the capitalist and the Soviet communist systems and rapid growth of the Soviet economy were presumably conducive to the rise of the welfare states in North Atlantic capitalism into the 1950s. This threat was, 


\subsection{Consumer goods and services}

It was within this context that the "economic parity across major regions of the world around 1800-and for several millennia before this_-was replaced for the most part by growing regional disparities." ${ }^{12}$ Where colonialism could strengthen its hold on local populations, the situation of these populations deteriorated. The Indian economist Utsa Patnaik correctly observed: “a surge in exports from plantations and from peasant agriculture, but always at the expense of falling foodgrains output and availability for colonized populations, reducing their nutritional standard and even leading to the extreme outcome of famine." She therefore argues that there is an "inverse relation between primary exports and domestic food grains availability." The reason for this is simple: "There is a limited supply of tropical lands and if heavy external demands are made on its productive capacity while insufficient investment is put in, then history demonstrates that the satisfaction of domestic needs is not possible and local populations are plunged into undernutrition and poverty." Thus emerges "a global asymmetry of primary productive capacities relative to demands on them”. ${ }^{13}$

The other side of the coin was the development of effective demand in the metropoles. During the 19th century tropical consumer goods more and more changed from luxury commodities to commodities consumed by working-class families as well. The underlying reason for this shift probably was the increase of real wages: The more technologically advanced the metropolitan production of consumer goods became, the cheaper these consumer goods, and the higher the level of real wages. Growing purchasing power of working-class families resulted directly in an increasing demand for tropical products, since these were new, different, exotic, etc. ${ }^{14}$ And, it led indirectly to increased demand for tropical products as soon as the supply of equivalent products from temperate climate zones proved to become insufficient given the growing consumer interest. For example: "During the late decades of the 19th century the European demand for edible fats began to outrun mid-latitude supplies, and the coconut began its rise as an item of

however, relatively short-lived. The Soviet Union was a distinctive social formation without endogenous dynamics, and its stagnation and downfall were inevitable.

12 M. Shahid Alam, "Global Disparities since 1800: Trends and Regional Patterns", Journal of World-Systems Research, 12, 2 (July 2006): 37-59, at 52-53.

13 Utsa Patnaik, The Republic of Hunger and Other Essays (Gurgaon: Three Essays Collective, 2007), 2-3.

14 Wolfgang Schoeller, Die offene Schere im Welthandel: Und wie sie zu schließen ist (Heilbronn: Distel Verlag, 2005), 31. 
export agriculture in the Asiatic tropics." ${ }^{15}$ Something similar seems to have happened in the case of West-African palm oil that was used for soap, candles, etc. In any case, since the late 19th century, tropical products increasingly entered the consumption of low- and middle-income groups.

It is likely that Northern working-class consumption of (sub-)tropical textiles, such as cotton, increased. But it is very difficult to substantiate this hypothesis empirically. Studies of family budgets almost always give figures for "clothing", without further specification. And the historians writing on class specific dressing habits mainly focus on the period until 1800 or $1850 .{ }^{16}$

The (slowly) growing consumption of tropical goods in the North, also by wage-earners, and increasing exploitation of workers and peasants in the South, had a very positive effect on the Northern economies. In the Dutch case, Buelens and Frankema conclude that:

The extraordinary profitability of the 'cultivation system' introduced by the Dutch on Java in the 1830s, contributed substantially to the economic development of the metropole. At its peak, in the 1850s, the forced cultivation of sugar, tea, indigo and coffee by Javanese peasants contributed an estimated $52 \%$ to Dutch central tax revenues and an estimated $4 \%$ to Dutch GDP. The net surplus on the Indonesian balance of payments was used to service high levels of Dutch state debt, to finance Dutch infrastructural investments and to subsidize the less 'productive' Dutch colonies in the West Indies. [...] We find that returns to FDI in the Netherlands Indies during 1919-1928 were impressive (14.3\%), almost 3 percentage points higher than the world average. During 1929-1938 the tides turned, with an average annual rate of return of $-2.8 \%$ compared to a world average of $2.2 \%$. Compared to the general rate of return on the Amsterdam stock exchange, the returns to colonial FDI were considerably higher: $2.1 \%$ for the period 1920-1939 versus $5.4 \%$ for our sample $1919-$ 1938. However, returns to FDI in the Netherlands Indies were subject to a higher degree of volatility and became worthless after 1940. We will argue that high returns to colonial FDI in tropical agriculture were underpinned

15 J.E. Spencer and Ronald J. Horvath, "How Does an Agricultural Region Originate?” Annals of the Association of American Geographers, 53, 1 (March 1963): 74-92, at 83.

16 See e.g., Giorgio Riello and Prasannan Parthasarathi (eds), The Spinning World: A Global History of Cotton Textiles, 1200-1850 (Oxford: Oxford University Pres, 2009), or Beverly Lemire, Global Trade and the Transformation of Consumer Cultures. The Material World Remade, c. 1500-1820 (Cambridge: Cambridge University Press, 2018). 
by repressive colonial labour policies and cheap access to land, but also may have partly reflected a higher risk-premium. ${ }^{17}$

\subsection{Employment}

The uneven global development created jobs in de metropoles as well, for instance in the textile industries, and in shipping. The British Fair Trade League, founded in 1881, received enthusiastic support from British cotton operatives.

The Lancashire - and what is less often appreciated, the Scottish - textile industry did export large quantities of goods of all kinds all over Africa." Therefore, "The English working-man did not necessarily mistake his own interest in this. If goods could not be sold, men could not be employed. ... Their support for imperialism, which Engels noted, may well not have been, as Lenin supposed, simply the result of clever deception by the bourgeoisie. ${ }^{18}$

Charles Guillaume Cramer, a leading social-democratic expert on colonial affairs, said at the so-called "Colonial Congress" of the Dutch Labour Party (SDAP) in 1930:

What are at present the existing interests of the Dutch working class in the colonial question? The colonial wage sources can be split up as follows:

1. Drainage: the outflow of profits made by land reclamation and the exploitation of the Indonesian worker. The profits from this source for the Netherlands can be estimated at on average 400 million guilders per year. Naturally, this profit creates employment; capitalized at 10 per cent, it amounts to 17 per cent of the national capital.

2. Market for Dutch industry. In 1920 the total value of exports was 1700 million guilders, of which 14 per cent went to Indonesia. In 1927 these figures were 1900 million guilders and 7.2 per cent. The textile industry exported in 192267.1 per cent of its total production to Indonesia. In 1928 this figure had decreased to 55.9 per cent....

3. Market for personal labour power. According to Van Gelderen (Socialistische Gids 192 1, p. 99) 43,500 Europeans have leading positions in

17 Frans Buelens and Ewoud Frankema, "Colonial Adventures in Tropical Agriculture: New Estimates of Returns to Investment in the Netherlands Indies, 1919-1938", Cliometrica, 10, 2 (2016): 197-224, at 198-199.

18 M.E. Chamberlain, "Imperialism and Social Reform", in British Imperialism in the Nineteenth Century, ed. C.C. Eldridge (London and Basingstoke: Macmillan, 1984), 148-167, at 160, 159. 
Indonesia. This is the 'upper layer.' The number of people originating directly from the Netherlands is roughly 40,000.

For an estimate of what an immediate severance of the colonial ties would mean for the Dutch workers, the speaker consulted our competent fellow party member Dr Tinbergen; he calculated, globally of course, a loss of employment for 150,000 Dutch workers that is about 10 per cent of the total number. ${ }^{19}$

\section{Second period: the era of Fordism and post-Fordism, from the 1940 s to the present}

With the rise of the second division of labour, industrialization got under way in the South. This trend was, of course, considerably strengthened when from the 1980s-90s the People's Republic of China started to evolve into an emerging capitalist superpower. The new international division of labour has extended all over the world, resulting in accelerating "globalization." As a consequence, the world's working class has been growing and changing rapidly. Seemingly contradictory trends have been taking place in labour settings: on the one hand transcontinental connections have become denser and have been intensified, making the world appears increasingly homogeneous - that is the well-known "globalization" - while on the other hand fragmentation and heterogenization are ongoing as well. Homogenization is clear in part from the continuously increasing share of employees in the world population: the percentage of pure wage dependents ("employees") rose between 1991 and 2018 from over 41 to over 51 per cent.20 In that sense, we see an ongoing proletarianization that has progressed the most in the advanced capitalist countries. It is estimated that in developed economies wage earners represent around 90 per cent of total employment. In developing and emerging economies employees may, however, represent as little as 30 per cent or less of total employment. ${ }^{21}$

19 Verslag van het koloniaal congres der Sociaal-Democratische Arbeiderspartij in Nederland, gehouden op zaterdag 11 en zondag 12 januari 1930 te Utrecht (Amsterdam: N.V. De Arbeiderspers, 1930), 13-14. Tinbergen was the economist Jan Tinbergen (1903-94), co-recipient of the first Nobel Prize for Economic Sciences in 1969. The reasons for the Dutch Social Democratic (and Communist) opposition to Indonesian independence are explored in Maurice Ferares, De Revolutie die Verboden werd. Indonesië, 1945-1949 (Amsterdam: Uitgeverij Abigador, 2014).

20 ILO WESO Data Finder: https://www.ilo.org/wesodata

21 https://www.ilo.org/global/topics/wages/minimumwages/beneficiaries/WCMS_436463/lang--en/index.htm 
Paralleling this trend, ever greater numbers of workers worldwide maintain direct economic contacts with one another, even though many are probably unaware of this. Transnationalization of labour processes, which started gradually in the 1960 s and accelerated since the 1980 s, has been crucial in this process. As a result, goods manufactured in one country are increasingly assembled from components produced in other countries, which in turn contain subcomponents made in still other countries. This process - also known as "slicing up" or "unbundling" supply chains - started at about the same time in North America (twin plants in Mexico and the United States) and East Asia, followed somewhat later by Europe, where Spain and Portugal joined the European Union in 1986, and where East-European "socialism" collapsed in the early 1990s. ${ }^{22}$

Transnationalization has had sweeping consequences for the world working class. First, a growing share of employees is part of global supply chains. The ILO's World Economic and Social Outlook 2015 report estimated that

in 40 countries representing 85 per cent of world gross domestic product and covering approximately two-thirds of the global labour force, the number of global supply chain-related jobs increased by 157 million or 53 per cent between 1995 and 2013, resulting in a total of 453 million global supply chain-related jobs in $2013 .{ }^{23}$

This equals one quarter of the employees. While transnationalization has greatly boosted industrialization in the Global South, the jobs created are largely unskilled and substandard and are increasingly - especially in the Global South - performed by women. The International Trade Union Confederation notes:

Eighty per cent of world trade and $60 \%$ of global production is now captured by the supply chains of multinational companies. The majority of supply chain workers are trapped in insecure and often unsafe jobs with poverty wages and long hours. Informal work, forced overtime and slavery are also found in the mix. A recent ITUC report shows that 50 of the world's

22 Richard Baldwin and Anthony J. Venables, "Spiders and Snakes: Offshoring and Agglomeration in the Global Economy." Journal of International Economics, 90, 2 (2013), 245-254, at 245-246.

23 World Employment and Social Outlook 2015. The ILO has noted on this subject: "The quantity of employment in global supply chains is difficult to estimate, as national employment statistics do not distinguish between different types of workers engaged in global supply chains, nor do they fully capture informal and non-standard forms of work. Furthermore, it is difficult to discern the percentage of workers supplying global buyers or domestic buyers and whether any domestic firms are supplying global supply chains indirectly without being direct exporters." (pp. 18-19) 
largest companies directly employ just $6 \%$ of the workers in their supply chains - the remaining $94 \%$ are part of the hidden workforce of global production. ${ }^{24}$

Within global supply chains core firms and intermediaries earn by far the most, and producers in developing countries make considerably less. The Samsung Galaxy S7, which retailed at 809 US dollars in 2016, illustrates this point. "Costs for components like the touchscreen were 249.55 US dollars, manufacturing costs were not more than 10 US dollars and, hence, total factory costs not more than 260 US dollars.”25

\subsection{Goods and services}

Within this context of increasing global connectedness, the part of Southern goods and services in the consumption pattern of Northern workers is likely to have grown significantly. Let me give three examples. First: mass motorization, which began in the 1920s in the United States and spread to the other advanced capitalist countries, especially after World War II. The enormous diffusion of cars implied, amongst many other things, a significant growth of rubber consumption, in particular for the tires. ${ }^{26}$ The miserable labor conditions on the tropical plantations where this rubber was and is produced are well-known. ${ }^{27}$ Second the cell phone, the global diffusion of which has been nothing less than explosive. The number of cell-phone

${ }_{24}$ https://www.ituc-csi.org/supply-chains-resources-hub. This hidden workforce thus concerns about 116 million workers.

25 Hansjörg Herr and Christoph Scherrer, "Trade, Global Value Chains and Working Conditions", in Who Benefits from Trade? Findings on the Link between Trade and Labour Standards in the Garment, Footwear and Electronics Industries in Bangladesh, Cambodia, Pakistan, and Vietnam (Bonn: Friedrich-Ebert-Stiftung, 2017), 1-8, at 2-3. See also Jason Dedrick, Kenneth L. Kraemer, and Greg Linden, "Who Profits from Innovation in Global Value Chains? A Study of the iPod and Notebook PCs", Industrial and Corporate Change, 19, 1 (February 2010): 81-116, but this study does not start at the beginning of the supply chain (mining coltan in the Democratic Republic of Congo, etc.), so that the chain ostensibly connects only East Asia with the United States.

26 Naturally, the diffusion process was uneven. Australia and Britain were faster, Germany was slower. See T.C. Barker, “The International History of Motor Transport," Journal of Contemporary History, 20, 1 (January 1985): 3-19, at 6.

27 See e.g., Tu Binh Tran, Red Earth: A Vietnamese Memoir of Life on a Colonial Rubber Plantation (Athens, OH: Ohio University Centre for International Studies, 1985); P. Ramasamy, "Labour Control and Labour Resistance in the Plantations of Malaya”, Journal of Peasant Studies, 19, 3-4 (1992): 87-105; Adam Hochschild, King Leopold's Ghost: A Story of Greed, Terror, and Heroism in Colonial Africa (London: Pan, 2002); and Margaret Slocomb, Colons and Coolies: The Development of Cambodia's Rubber Plantations (Bangkok: White Lotus, 2007). 
subscription has increased from 23,500 in 1980 to 2.7 billion in 2019.28 And as we all know, the rare metals used to build cell phones are frequently mined under horrendous circumstances. Cobalt and coltan, for example, are often produced in Sub-Saharan Africa by children, and violently oppressed workers. ${ }^{29}$ Third: the increase of tourism. Worldwide, tourism grew phenomenally from 25 million arrivals (overnight visitors) in 1950 to 808 million in 2005 , and to 1.4 billion in $2018 .^{30}$

\subsection{Employment}

Due in part to the second globalization, industrial jobs dropped sharply in the North, although there was little or no decline in industrial output there. As a result, goods manufactured in one country are increasingly assembled from components produced in other countries, which in turn contain subcomponents made in still other countries. One quarter of all employees worldwide is part of global supply chains.

If the empirical data reflects real trends, then this suggests that Ulrich Brand and Markus Wissen are justified in saying that "the increase of productivity and material prosperity in the capitalist centres depends on a world resource system and international division of labour that favours the global North and is rendered invisible through the imperial mode of living, so that the domination and power relations it implies are normalized." ${ }_{11}$

\section{How to continue?}

Two kinds of questions seem to follow from the above. The first question is empirical: how can we test the relational-inequality hypothesis? For a solid examination we would need at least three bodies of knowledge:

28 Jonathan C. Comer and Thomas A. Wikle, "The Worldwide Diffusion of the Cellular Telephone, 1995-2005," The Professional Geographer, 60, 2 (2008): 252269, at 253; https://techjury.net/stats-about/smartphone-usage/

29 For example, Child Labour in Mining and Global Supply Chains (Geneva: International Labour Organization, 2019); “Tech Giants Sued over Child Deaths in DRC Cobalt Mining," Financial Times, December 16, 2019 (on Apple, Google, Microsoft, Dell and Tesla).

so United Nations World Tourism Organization, World Tourism Barometer (Madrid: UNWTO, 2019).

31 Ulrich Brand and Markus Wissen, The Limits to Capitalist Nature: Theorizing and Overcoming the Imperial Mode of Living (London and New York: Rowman \& Littlefield International, 2018). 
- First, detailed knowledge of the long-term development of Northern working-class consumption patterns - through family budgets reconstructions and other methods - and their impact on purchasing power and job security.

- Second, we would need to know a lot more about transcontinental supply chains - chains (including transport) that in the course of time have become much more numerous and complicated. ${ }^{32}$

- Third, we would have to combine this knowledge with the already extensive (but still imperfect) knowledge of the employment and working conditions of the Southern working classes.

(It is important to emphasize that the North-South problem has been 'globalized' in recent years, for example, in the case of Chinese industries outsourcing labour to other parts of Asia and Africa, where even lower wages can be paid.)

The second question is political: what kind of consequences does relational inequality have for radical politics? Is the Northern working class so corrupted by its benefiting from Southern exploitation that it can no longer be considered as an anti-capitalist subject? And if so, should we exclusively pin our hopes on the exploited labouring poor of the Global South? ${ }^{33}$ Should the wage-earners in the Global North drastically change their lifestyle and in that way undermine the "Imperial Mode of Living", within the paradigm

32 The technical complications of transcontinental chain analysis are impressive. "In this context, it is well known that international trade statistics fail to offer a good picture of trade integration and the global division of labour. They cannot answer the question 'who produces for whom?' To illustrate the point, let us take an example extracted from Benhamou (2005) [...]. The firm Burberry sends perfume bottles from France to Shanghai to be decorated with a Scottish pattern before bringing them back to be sold on the French market. Standard trade statistics suggest that France is exporting perfume bottles to China and China is exporting perfume bottles to France. Yet France does not export anything for Chinese consumption, as the perfume bottles are consumed in France. China simply exports decoration for French consumption. Suppose the pigments used for the decoration of the perfume bottles are imported by China from Japan. This Japan-China trade flow does not mean that China consumes Japanese products, as the final consumer is in France. Unravelling these long supply chains is impossible using simply trade statistics." Guillaume Daudin, Christine Rifflart and Danielle Schweisguth, "Who Produces for Whom in the World Economy?," The Canadian Journal of Economics / Revue canadienne d'économie, 44, 4 (November 2011): 1403-1437, at 1404. The reference is to Laurence Benhamou, Le grand Bazar mondial: la folie aventure de ces produits apparemment 'bien de chez nous' (Paris: Bourin, 2005). This seems to be the option advocated by Zak Cope in his books. 
of the capitalist mode of production? Or ...? Can trade unions play a role in this context and, if so, how? To what extent is the relational inequality a central tenet of anti-capitalist movements and can it serve as a lever in global emancipation of the working class? 
Título: Trabajadores que se benefician de la explotación de otros trabajadores

Resumen: Con frecuencia, con demasiada frecuencia, la solidaridad de la clase trabajadora a nivel internacional sigue siendo frágil, condicionada o inexistente en la práctica, más allá de la retórica. En el presente artículo se explora una posible explicación: los trabajadores del Norte se benefician de la explotación de los trabajadores del Sur mediante productos y servicios baratos y oportunidades de empleo adicionales. Por ejemplo, a los asalariados del Norte les resulta muy accesible comprar camisetas porque sus salarios reales son mucho más altos que los salarios reales de los trabajadores del Sur. Llamo a esto una desigualdad relacional dentro de la clase obrera mundial: algunos trabajadores están mejor porque otros están peor. El documento presenta un esquema histórico muy tentativo de la desigualdad relacional mundial desde la década de 1830.

Palabras clave: solidaridad, desigualdad, consumo, empleo, división internacional del trabajo, modo de vida imperial

Título: Trabalhadores que se beneficiam da exploração de outros trabalhadores

Resumo: Com frequência, com demasiada frequência, a solidariedade da classe trabalhadora em nível internacional permanece frágil, condicionada ou inexistente na prática, qualquer que seja a retórica. Este artigo explora uma possível explicação: os trabalhadores do Norte se beneficiam da exploração dos trabalhadores do Sul através de produtos e serviços baratos e oportunidades adicionais de emprego. Por exemplo, os assalariados do Norte acham muito acessível comprar camisetas porque seus salários reais são muito mais altos do que os salários reais dos trabalhadores do Sul. Chamo isso de desigualdade relacional dentro da classe trabalhadora mundial: alguns trabalhadores estão em melhor situação porque outros estão em pior. O artigo apresenta um esboço histórico muito provisório da desigualdade relacional global desde os anos 1830 .

Palavras-chave: solidariedade, desigualdade, consumo, emprego, divisão internacional do trabalho, modo de vida imperial 